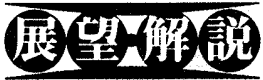

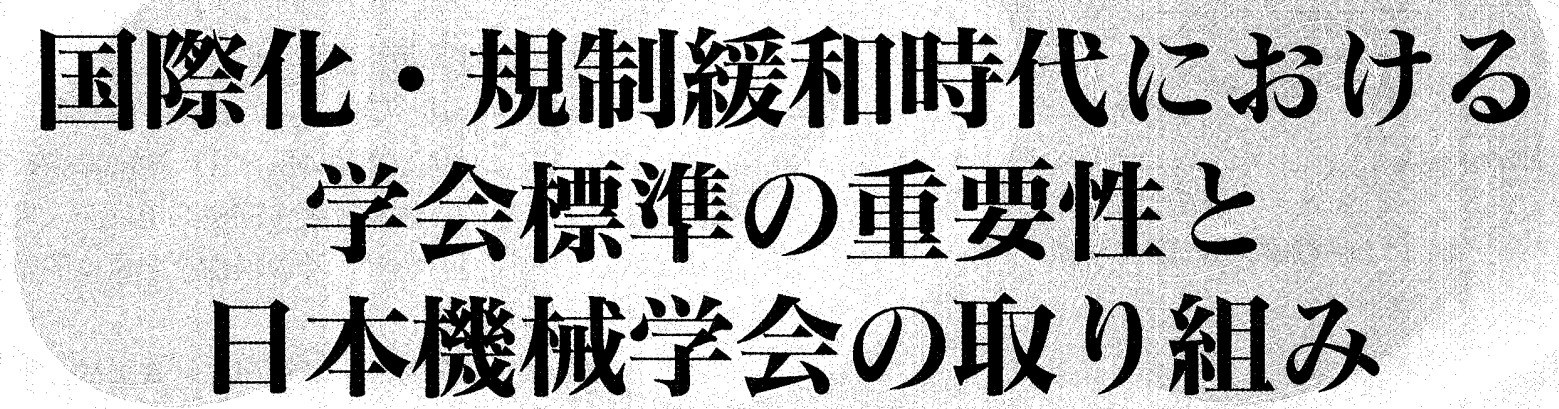

Voluntary Standards at the JSME in Globalization and De-Regulation Era

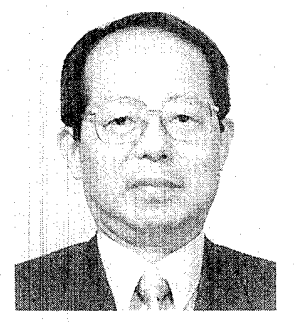

成合 英樹

Hideki NARIAI

○1938 年 10 月生まれ

1967 年東京大学大学院博士滥程機械工学尃政修 了, 運輸省船船技術研笁所を経て, 1980 年筑波 大学助教授, 現在同大学教授, 日本機械学会第

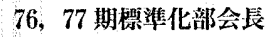

○妍究・尃門テーマは熱工学, 原子動力, エネルギ -I学

○正員, 筑波大学機能工学系

(宁 305-8573 つくば市天王台 1-1-1)

E-mail : nariai@kz.tsukuba.ac.jp)
1はじめに

この小特集号でそれぞれ触れられているように，現在， 基準や規格など標準の問題が極めて重要になっているが, 要約すると以下のようになろう。すなわち，我が国では明 治以来，海外に学び追いつくこと，そして国家による強い 規制により産業育成保護と国民の安全確保を行うことを基 本的方策としてきた。しかし, 最近のグローバリゼーショ ンの中で国家間の輸出入は増大し, その際, 各国の基準や 規格が異なることが問題となりつつある。このような流れ の中で，工業立国の我が国として大きく三つの問題があが ってきた。

第一は，世界に通用する基準・規格による製品製造を行 わないと輸出ができないこと，逆に言えば基準・規格をお さえることが貿易戦略上極めて重要であり，主要国はこれ に極めて熱心なのに我が国ではのんびりしていることであ る.

第二は，我が国独自の規制が多く諸外国から貿易障壁上 クレームをつけられることが多いことであり，第三は，我 が国の国家による基準・規格が細かいことまで規定してい るため最新の知見を即座に反映して改訂ができず，製品の 価格が高くなり海外に勝てなくなっていることである.

我が国では最近，国際基準への関心の高まりと規制緩和 が行われるようになったが，これらを進める上で，技術的 に最高の知見を有する技術者集団である学会への期待も增 大しつつある。日本機械学会の取り組みの現状と今後を述 ベてみたい。

\section{2 学会の役制と取り組み}

日本機械学会ではこれまでJIS（日本工業規格）やISO （国際標準化機構）等の原案作成に協力すると共に，独自 の日本機械学会基準を作成してきたが，その活動は必ずし 


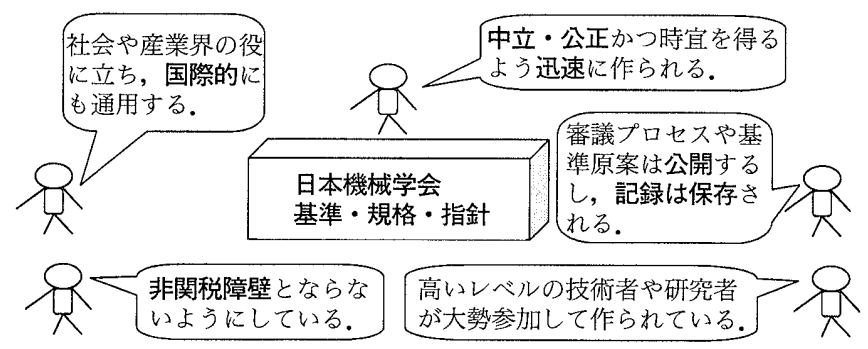

図 1 日本機械学会の基準の特徴

も活発でなかった，理由として，我が国では基準や規格は 国が作るもので，学会などの民間の基準は重要と考えられ ていなかったこと，そのため学会として基準を作っても経 済的に成り立たない場合が多かったことである。しかし， 最近の規制緩和による国の基準・規格類の機能性化とそれ に伴う審查基準として民間基準の活用等の動きにより流れ が変ってきた。

これまで我が国では明治以来の海外技術導入の経緯か ら，国の基準・規格といえ基本的には海外基準・規格に依 存していた部分が多い.しかし，技術の先進国となりさら に独自の基準・規格を作らねばならなくなると，専門家を 含めた技術者集団の知識が必要である。さらに，WTO/ TBT 協定（貿易の技術的障害に関する協定）の観点か ら，基準作成には透明性が要求されている．これらを満足 する団体として学会は最適の機関であろう.

しかし，これまでの学会はどちらかというと学術的な面 が強く, 場合によっては研究者集団のサロン的な雾囲気が あった，学会の組織や運営にもその影響が出ていたが，基 準や規格は，実践技術の集約であるため，学会の体質も若 干変える必要が出てきた，日本機械学会では，第二世紀の 学会活動の中心に社会に開かれた，社会に連携する活動を 行うこととし，基準・規格作りもその中の主要な活動とな っている.

\section{3. 発電用機械設備の規格作成}

1997 年 6 月に電気事業法の改正があり，原子力を除く 発電設備のこれまでの省令告示が機能性化され，審查基準 として民間基準が活用されることになった．我が国の発電 用機械設備のこれまでの省令告示は，主に米国機械学会 (ASME) の基準・規格に基づいて作成されていたが，こ のやり方をそのまま続けることは，日本の技術力向上にと つて好ましくない等の理由から日本機械学会で独自に規格 作成を行うこととして，1997 年 10 月に標準化部会の下に 発電用設備規格委員会を設置し活動を開始した。

この規格委員会の特徵は，基準・規格制定で必要とされ る中立性, 公正性, 公開性を確保した点である。その主な 具体例をあげると以下のようになる。
（1）委員構成が偏らないこと，すなわち，委員は 5 種以 上の業種が含まれ, 一つの業種の委員が $1 / 3$ を越えないこ と.

（2）委員会の開催や議事録を公開すること.オブザーバ として参加し意見を述べることが可能.

（3）基準原案に対する投票の明確化. 規約に投票採決方 法が規定されている．例えば第 1 回投票では一人でも反対 票があれば採決を見合わせ，その理由を全員に開示した上 で再度投票するなど.

（4）基準原案の公臬審査。基準原案は委員会可決後一定 期間一般に公開して意見を求めた上で正式に決定する。

（5）記録の保存．すべての記録は一定期間保存され，規 格作成過程が後になっても分かる。

この規格委員会は，下部組織として專門委員会（現在, 火力と原子力の二つ), 分科会, 作業会を持っており, 下 の組織から順次規格原案があがってくるようになってい る. 現在, 火力発電設備の規格原案がほぼできあがってい る段階である。

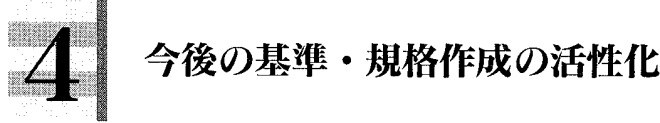

以上のような活動は，これまで標準化部会で進めてきた 基準作りの活動を大きく越えるものであり，標準化部会を 中心とした体制や規程類を見直し強化する必要がある.今 後の日本機械学会での基準作りには, 発電用設備規格委員 会と同様，公正，中立，公開性を持ったものである必要が あるが，すでに 1998 年 10 月にできた日本機械学会基準 S 012 「配管内円柱状構造物の流力振動評価指針」におい ては，原案作成において上に記した（1）から(5)までの要件 を満たすよう試行された。標準化部会としてこれをさらに 進めるべく各種の規程類を整備しつつある.また同時に， 基準・規格作成における倫理規定がある，基準・規格類は 産業界にとっては死活にも関係する極めて重要なものであ るゆえ, 基準・規格作成委員会における委員の倫理を規定 しておく必要があろう。図 1 に日本機械学会の基準の目指 す特徵を示す。

さらに, 今後 ISO 等国際的な基準が大きな問題となる と考えられる。これまでも日本機械学会として ISO 活動 を行ってきたが, むしろ参加者のボランティア的な活動に よっていた. 今後もっと積極的に対応すべく標準化部会内 にグループを作って活動を開始している.

以上のように, 日本機械学会においては標準化部会を中 心として活発な基準・規格・指針作りに乗り出した．発電 用設備に限らず，各分野において日本機械学会の場を基準 作成に利用していただきたい。 その活動に，現場の技術者 に積極的に参加していただきたいし，また，産業界・官界 からの積極的な支援をお願いしたい.

（原稿受付 1999 年 1 月 8 日） 